\title{
United States Immigration Policies in the Trump Era
}

\author{
Amadu Jacky Kaba \\ Department of Sociology, Anthropology and Social Work Seton Hall University, South Orange, New Jersey, USA \\ Email:kabaamad@shu.edu
}

How to cite this paper: Kaba, A. J. (2019). United States Immigration Policies in the Trump Era. Sociology Mind, 9, 316-349. https://doi.org/10.4236/sm.2019.94021

Received: August 9, 2019

Accepted: October 26, 2019

Published: October 29, 2019

Copyright $\odot 2019$ by author(s) and Scientific Research Publishing Inc. This work is licensed under the Creative Commons Attribution International License (CC BY 4.0).

http://creativecommons.org/licenses/by/4.0/

\begin{abstract}
This paper examines U.S. immigration policies in the Trump era. By 2017, there were over 250 million international migrants in nations across the world. The world has progressed substantially primarily due to this phenomenon. The GDP of the world increased from \$22.6 trillion in 1990 to $\$ 80.738$ trillion in 2017 . The number of billionaires in the world increased from 140 in 1987 to 2153 in March 2019. The number of millionaires in the world in 2017 was 42.155 million. The paper claims that the United States has played an important leadership role in not just hosting the largest share of international migrants, but it has also encouraged other wealthy nations to accept more immigrants. The paper points out, however, that all of this progress is now being undermined by President Donald Trump and his administration by implementing immigration policies that are sharply reducing the number of immigrants entering the United States during his presidency and also calling for European nations to sharply reduce immigration. Immigrant and non-immigrant visas to the United States have all experienced a sharp decline during the Trump presidency. Among the causes of international migration are, fleeing violence, family reunification, education, and job/employment. Among the implications of the Trump administration's immigration policies are loss of skilled immigrants, decline in U.S. innovation, decline in the U.S. economy, negative effects of family separation, and the stagnation or decline of the U.S. population.
\end{abstract}

\section{Keywords}

Trump, Refugees, Immigration, International Migration, Visa, Green Card

\section{Introduction}

If one were to put aside nation to nation or world regional comparisons, the world has experienced substantial progress as it relates to human development 
in the past three decades. For example, according to the World Bank, the gross domestic product (GDP) for the world or global GDP in 2017 was $\$ 80.738$ trillion. In 1990, it was $\$ 22.607$ trillion (World Bank national accounts data, 2019). The number of billionaires and millionaires in all regions of the world has increased substantially. For example, according to Forbes Magazine, as of March 5, 2019, there were 2153 billionaires in the world (with 607 or $28.2 \%$ in the United States), with a total net worth of $\$ 8.7$ trillion (Billionaires: The Richest People in the World, 2019). According to Kilachand (2012), “in 1987, Forbes found 140 billionaires including 96 outside of the U.S." The number of millionaires in the world in 2018 was 42,155,000; 18,648,000 (44.2\%) in North America; 12,439,000 (29.5\%) in Europe; 6,606,000 (15.7\%) in Asia-Pacific; 3,480,000 (8.3\%) in China; 520,000 (1.2\%) in Latin America; 343,000 (0.8\%) in India; and 120,000 (0.3\%) in Africa (Global Wealth Report 2018, 2018: p. 36).

The number of people with at least a tertiary education has increased significantly across all regions of the world. For example, an average of $26 \%$ of people in the Organization for Economic Cooperation and Development (OECD) nations aged 25 - 34 years had attained at least a tertiary education in 2000. In 2016, that figure increased to 43 percent; $24 \%$ and $40 \%$ respectively in the European Union. For G20 nations, the average was 31\% in 2010 and 35\% in 2015 (Table A1.2. Trends in educational attainment of 25 - 34-year-olds, 2017). The number of college students studying overseas increased from 1.1 million in 1980 to 4.7 million in 2015 (Montoya, 2018).

Despite recent reports of increasing religious restrictions in increasing numbers of countries in the world (Kishi, 2018), international migration has resulted in millions of people who can now freely practice their religions in increasing numbers of countries.

One can argue that a primary factor that contributed to the many examples of positive human progress across the world in the past three decades presented above is international migration. According to the United Nations, "an international migrant is a person who is living in a country other than his or her country of birth" (International Migration Report 2017, 2017: p. 3). For example, international migration resulted in highly skilled or talented people moving to societies that immediately put them to work and let them harness their talents. The societies or nations they left behind also benefited in at least one way-remittances, which are now far more than foreign aid to developing nations (Naudé, 2012). For example, according to the United Nations, an estimated $\$ 413$ billion was sent home in remittances in 2016 by migrants from developing nations. These remittances account for an important source of income for the households receiving them. These funds increase the living standards of families and neighborhoods because they are invested in housing and infrastructure, sanitation, health and education. The host countries, which are usually relatively wealthy, also tend to benefit significantly from immigrants because they tend to be employed in critical sectors of the economy and they also "... create jobs as entrepreneurs, and pay taxes and social security contributions. Some migrants 
are among the most dynamic members of the host society contributing to the development of science and technology and enriching their host communities by providing cultural diversity (International Migration Report 2017, 2017: p. 1; also see Kaba, 2004; 2009). As Khullar et al. (2017) also point out pertaining to the over 160,000 foreign medical graduates working in the United States, while this phenomenon of such a large number of foreign doctors mostly from developing countries working in the United States is known as "brain drain" because it leads to shortages of medical doctors "... in low-income nations contending with endemic diseases. This loss likely is offset only partially by any 'brain gain': clinical and educational connections between the United States and developing countries as well as remittances sent home to family and communities" (p. 585).

One nation that can present evidence to have supported international migration flows as we know them today is the United States. The United States has played a leadership role in not only allowing tens of millions of people to immigrate into the country in the past three decades, it also played an important role in influencing or convincing other relatively wealthy nations (including those in Europe and Oceania) or other nations to accept immigrants or increase their immigration numbers. Even to this day, the statistics section in this paper illustrates that the United States leads the world in the number of immigrants it hosts. Singh (2018) points out that “... more than one million migrants and refugees have travelled to Europe in 2015, four times the total from 2014” (p. 178). A significant proportion of those immigrants are people fleeing wars in Syria and Iraq. The United States played a role in influencing European nations to accept more immigrants. To do so, the United States had to illustrate to the Europeans and the world that it is willing to accept those same immigrants. For example, according to Bose (2018), refugee resettlement policy was formalized to become primarily a federal program in 1980 . Since that period the program has had many controversies. The Obama administration, for example, during the height of the Syrian civil war, took in 10,000 Syrian refugees in FY 2016 for a total intake of 85,000, and took in another 25,000 Syrian refugees in FY2017 for a total intake of 110,000 refugees. "Because of such trends, the United States in recent decades has been one of the most significant third country resettlement destinations in the industrialized world-in absolute numbers, if not per capita" (pp. 321-322). One reason why the United States came to have such moral authority to influence wealthy and non-wealthy nations to accept more immigrants is that the United States Congress opened up the country to immigrants in the 1960s, which is responsible for its current great racial, ethnic, religious and cultural diversity. According to Young (2017), the United States:

"Immigration and Nationality Act of 1965, which marked a momentous change ... of the entire migration landscape in the United States. The new law put an end to the quota system, and replaced it with a preference based on family relationships and professional skills. Throughout the 1980s, 1990s, and 2000s, the number and percentage of immigrants rose conti- 
nuously and steeply, and the ethnic makeup of the newest wave of immigrants changed significantly, with immigration from Asia and the Americas

eclipsing immigration from Europe" (p. 226).

However, during the start of the campaign in 2015 to become the Republican nominee in the 2016 United States presidential election, many Republican candidates began portraying immigrants in a very negative way, as if immigrants were responsible for most of the problems the country faces. No one individual candidate showed more hatred of immigrants and portrayed them in the worst manner possible than Donald Trump, who eventually won the 2016 presidential election and became president in January 2017. During the 2016 presidential campaign, Trump not only called for the United States to substantially reduce immigration, but he also did the opposite of previous American leaders by publicly calling for European nations to reduce or stop immigration altogether. $\mathrm{He}$ even publically supported the United Kingdom's vote to leave the European Union-Brexit (Wilson, 2017; Kaba, 2017a: pp. 9-11).

This paper examines the immigration policies of President Donald J. Trump's administration since it took control of the United States federal government in January 2017. The paper begins by presenting the factors responsible for international migration. Next, the paper presents the Trump administration's immigration policies. Next, the paper presents statistics on international migration, with a focus on United States immigration statistics before and during the Trump presidency. This will include all categories of immigrant and non-immigrants visas issued to applicants, refugee figures, and permanent residency and naturalization statistics. Finally, the paper presents the implications of the Trump administration's immigration policies.

\section{Factors Responsible for International Migration}

The dozens of factors that have been cited as responsible for international migration can be grouped into three broad categories: 1) religious freedom; 2) political freedom; and 3) economic freedom or opportunity. Among the dozens of mostly interrelated factors cited in the scholarly literature for international migration are: violence/civil conflict or war; refugee/asylum; educational attainment (especially higher education); family reunification; jobs/employment; high debt levels of nations; competition among developed or powerful nations; and inequality as a result of colonialism and globalization (Bose, 2018; Kaba, 2011: p. 190, 2017; Mazrui \& Kaba, 2016: pp. 85-87; Singh, 2018: pp. 180-181).

Violence has been cited as a major factor for international migration. According to Wood (2018), in 2015, 28 million children fled their home countries to other nations because of violence (p. 2). Wood (2018) adds that the migrants who are jailed by the U.S. government at the border with Mexico are mostly seeking asylum: “... from Guatemala, Honduras and El Salvador; chronically destabilised regions plagued by grave levels of human rights violations, insecurity, poverty, drug cartel infiltration, violence and corrupt justice systems. Crimi- 
nal gangs target children and mechanisms of exploitation and control are notoriously brutal" (Robbins, 2018: p. 2). These examples can fall under the category of political freedom.

It is quoted in Kaba (2011a) that:

"The factors driving international flows of migration in general and skilled migration in particular mostly involve global inequalities in development. In less developed countries, the educated are the ones most likely to perceive that they might be better off in some parts of the world than in others, and they are the ones best equipped to use their skills in such places. In general, the net flow of migrants-including skilled migrants-is directed toward the more developed countries of the world, with the United States at the apex of a hierarchy of complex flows, from relatively poorer to relatively richer economies" (p. 190; also see Kaba, 2009).

Explaining the impact of high levels of debt on international migration, especially from developing nations to developed nations, Heyer (2018) points out to research that: "... links deeper dynamics of debt servicing and extraction to new migratory flows .... 'predatory' forms of advanced capitalism, opaque transnational networks, and a global governance system geared to aiding corporations ..." (p. 156). Rose-Redwood and Rose-Redwood (2017) point out that the United States has "the largest share of international students globally ..." (p. 1). It is noted that in 2015 over two-thirds of international college students were "... in G20 countries, with 19\% studying in the United States, followed by $9 \%$ in the United Kingdom and 6\% in Australia" (Montoya, 2018). These examples can fall under the category of economic freedom or opportunity.

Heyer (2018) explains the moral responsibility of supporting immigration through family unification by citing a scholar who writes: “... Aquinas's order of charity for determining a nation's duties to immigrant families offers another application of relational justice to migration ethics" (p. 158). The scholar also “... proposes that Congress grant priority to regularizing undocumented Mexican immigrants who belong to mixed-status families 'out of a sense of beneficence toward the US citizens who love them"' (Heyer, 2018: p. 158; Grover et al., 2019). This example could fall under any of the three categories of religious freedom, political freedom or economic freedom or opportunity.

\section{Trump Administration's Immigration Policies}

Politicians in the United States are usually known to promise to do certain things but will not follow-up once they are in office. For example, Ronald Reagan was viewed as a far-right conservative during both his presidential campaigns in 1980 and 1984. Even to this day most conservative Republicans view him as a true conservative Republican who believed in law and order. Yet as Mazza (2017) points out: "Ronald Reagan was the last to lead an immigration reform package that responded, in part, to then-swelling ranks of foreign workers without legal status employed in US industries and agriculture. The 1986 
immigration reform bill 'legalized' 2.9 million immigrants" (p. 34).

What has shocked the American society and the international community is that President Donald Trump's harsh immigration rhetoric and promises to be tough on immigration during the 2016 presidential campaign, are being systematically implemented in the two and half years he has been president. As Lind and Zarracina (2019) point out, Donald Trump has: “... done more to crack down on immigrants-both those seeking to come and those already here-than most presidents have done in four or eight" Young (2017) notes that: "Trump famously launched his campaign by calling Mexican immigrants rapists and criminals .... He also continuously linked immigration to terrorism, called for 'a total and complete shutdown of Muslims entering the United States ..." (p. 218). Heyer (2018) points out that during the 2016 presidential elections Trump pledged: “... to deport undocumented immigrants and secure the border with Mexico, a country he charged with sending its criminals, drug dealers, and rapists. Anti-immigrant sentiment helped elect Trump: the most consistent chant at his rallies was 'Build the wall!' (pp. 146-147)”. Klingner (2018) points out that: "Trump promised to build a wall on the U.S.-Mexico border and suggested that it be funded by demanding that Mexico pay for it, taxing remittance monies that Mexican immigrants working in the United States send to relatives in ico ..." (p. 3; also see Kocher, 2017: pp. 165-166). According to Patel and Levinson-Waldman (2017): “Trump's inflammatory rhetoric on Islam, and more generally on immigrants and foreigners, defined much of his campaign and laid the foundation for the policies he would implement, the advisors he would put into place ..." (p. 2).

Today both legal and undocumented immigrants, their families and supporters are in constant fear of the immigration policies of the Trump administration. For example, Patel and Levinson-Waldman (2017) note that the Trump administration's immigration measures have resulted in "... growing fears that American Muslims have for their safety and the safety of their families" (p. 2). McHugh (2018) notes that the recent actions that the Trump administration has taken on immigration "... have deepened the sense of crisis in many immigrant communities" (p. 1). Gubernskaya and Dreby (2017) write that: "While it is not feasible to deport all 11.1 million unauthorized individuals, such measures amplify the fears of family separation among unauthorized immigrants, legal migrants, and US citizens alike" (p. 418). According to Lind and Zarracina (2019), the Trump administration's immigration actions have made: "the lives of those who are already here more precarious ... Anyway you slice it, more immigrants are more at risk than they were the day before Trump arrived."

Within the first ten days of taking over the office of president (January 20, 2017), Trump and his administration began implementing a number of policies he promised to act on during his campaign. They have continued to do so using presidential executive orders and directives for all two and half years he has been in office. Interventions by the federal courts, including the Supreme Court of the United States serving as a check on his immigration policies have not contained 
him and his administration enough to reduce the anxiety of immigrants in the country and those seeking to immigrate to the United States.

Among the policies that the Trump administration has been implementing are: aggressive and large scale deportations of undocumented immigrants and legal immigrants with minor legal or criminal offences; significant to substantial reductions in almost all categories of immigrant and non-immigrant visas, including $\mathrm{H}-1 \mathrm{~B}$ and other employment visas, student visas, and family unification visas; substantial reduction in the number of refugees accepted into the United States; officially banning immigrants from selected Muslim countries; extreme vetting of all individuals who apply for all types of visas; denying various types of applications without providing request for evidence or intent to deny; ending the Obama-era Deferred Action for Childhood Arrivals (DACA) and Deferred Action for Parents of Americans and Lawful Permanent Residents (DAPA) programs; enforce all court decisions to remove non-citizens from the United States; excluding immigrants from privacy protections; hiring substantially more immigration enforcement officers to make arrests of immigrants and patrol the U.S.-Mexican border; end the catch-and-release policy; increase mandatory minimum sentences for illegal reentry into the United States; reform laws on interior enforcement; end work authorization to spouses of $\mathrm{H}-1 \mathrm{~B}$ visa holders; end international entrepreneur parole; introduce ideological vetting or screening; strengthen and expand the e-verify program; reduce legal immigration; official presidential national emergency declaration to build a wall on the Mexican border; placing thousands of children and adults in detention facilities in what many claim are "cages" across the United States, with children separated from their parents; deporting parents while their children remain in detention in the United States; providing financial and other important resources to state and local governments who cooperate with U.S. immigration policies; threatening to punish local and state governments who try to protect the human rights of immigrants; threatening and punishing countries which refuse to cooperate with U.S. immigration policies; ending temporary protected status (TPS) for immigrants from El Salvador, Haiti, Honduras, Liberia, Nicaragua, and Sudan; arresting immigrants seeking refugee status or asylum at the U.S.-Mexican border; and preventing immigrants seeking asylum at the Mexican border from entering the United States (Cervantes \& Walker, 2017; Gubernskaya \& Dreby, 2017; Hiemstra, 2017; Heyer, 2018; Issuance of Certan RFEs and NOIDs, 2018; Khullar et al., 2017; Klingner, 2018; Kocher, 2017; Landgrave \& Nowrasteh, 2019; Latinos and the New Trump Administration, 2017; Lind \& Zarracina, 2019; Mayda \& Peri, 2017; McHugh, 2018; Patel \& Levinson-Waldman, 2017; Pierce \& Capps, 2017; Pierce et al., 2018ab; Presidential Proclamation on Declaring a National Emergency, 2019; Rose-Redwood \& Rose-Redwood, 2017; Thumpson, 2016; Wood, 2018; Young, 2017).

According to Lind and Zarracina (2019), "Under Trump, the departments of Homeland Security (which oversees Customs and Border Protection and Immigration and Customs Enforcement), Justice, and State have all taken steps to re- 
duce the number of immigrants coming to the US" (also see McHugh, 2018: p. 1). Pierce et al. (2018b) point out that from the moment he took over the U.S. presidency Trump made it clear that he intended to implement extreme immigration measures. In his first week he announced: “... a series of executive orders promising major changes to the U.S. immigration system, ranging from sharp cuts to legal immigration and the building of 'the wall' across the entire U.S.-Mexico border, to 'extreme' vetting of all applicants for admission" (p. 1). The authors add that eighteen months later the Trump administration continued with its tough immigration measures by substantially reducing the number of refugees allowed to enter the United States; eliminated temporary protected status for noncitizens; banned citizens from seven Muslim countries from entering the United States; requiring interviews for anyone who applies for a visa, including permanent residency (green card); substantially reduced the number of people eligible for asylum in the United States; and increasing the rigorous vetting of all visa applicants. These measures have slowed the visa processing time for applicants. The authors conclude that these immigration actions are primarily due to the Trump administration's goal to reduce overall immigration to the United States, and that "Many of these measures have already begun affecting immigrants, their families, employers, and the communities in which they reside" (pp. 1-2; also see Greene, 2019; Pierce et al., 2018a: p. 1). Heyer (2018) points out that immediately after becoming president, Trump's administration moved swiftly to act on his campaign promises by issuing Executive Orders (EOs) in his first few weeks "... that called for constructing a wall at the United States-Mexico border, a selective travel ban, and expansion of the nation's detention capacity and expedited removal practices" (pp. 146-147). Heyer (2018) adds that although some of these immigration actions by the Trump administration were challenged in federal courts “... enforcement raids have ensued in at least twenty states. The administration's internal enforcement measures and accompanying rhetoric have fanned the flames of nationalism, sown fear in immigrant communities, and eroded civic life" (pp. 146-147).

Pierce et al. (2018a) note that: "The Trump administration has not only broadened the discretion of immigration enforcement agents to detain unauthorized immigrants far beyond those who have committed crimes, but it has also restored a nationwide system (known as Secure Communities) for identifying unauthorized immigrants stopped by local police and insisted on greater institutional cooperation from local law enforcement in identifying and holding them" (p. 1). Gubernskaya and Dreby (2017) point out that: "Under the new guidelines imposed by the administration, all unauthorized immigrants, and those with legal status who have criminal convictions, are eligible for deportation regardless of familial ties in the United States" (p. 418).

According to Mayda and Peri (2017), in addition to two EOs that restrict immigrants from Muslim nations from entering the United States, reorganized the system for deporting undocumented immigrants, and build a wall on the U.S.-Mexican border, a third EO “... promotes the 'Buy American and Hire 
American' principle and promises to overhaul the $\mathrm{H}-1 \mathrm{~B}$ visa programme, making it harder for US companies to hire foreign temporary workers" (p. 69; Gubernskaya \& Dreby, 2017: p. 418; Klingner, 2018: p. 4). Pierce et al. (2018a) also add that: "The Trump administration has signaled it plans to end an Obama administration program to give work authorization to spouses of $\mathrm{H}-1 \mathrm{~B}$ visa holders (temporary visas granted to immigrants in certain professional categories)" (p. 16)

According to Rose-Redwood and Rose-Redwood (2017), although one of Trump's first EO on January 27, 2017, barring people from the following Muslim-majority nations, Iran, Iraq, Libya, Somalia, Sudan, Syria, and Yemen, from entering the United States, was blocked by U.S. federal courts, on March 6, 2017, he signed another EO "... reinstating the travel ban with some modifications (e.g., Iraq is no longer included on the list of banned countries)" (p. 1; also see Khullar et al., 2017: p. 584). The U.S. Department of Homeland Security once had a policy of officially informing applicants for various visa applications about why they were denied. However, on July 13, 2018, the U.S. Department of Homeland Security published a policy memorandum which instructed officials who adjudicate U.S. citizenship the responsibility or authority “ ... to deny an application, petition, or request without first issuing a Request for Evidence (RFE) or Notice of Intent to Deny (NOID) if initial evidence is not submitted or if the evidence in the record does not establish eligibility" (Issuance of Certain RFFs and NOIDs, 2018).

According to Pierce et al. (2018b), the Trump administration is actively in the process of ending the Obama-era Deferred Action for Childhood Arrivals (DACA) program. The program "currently provides protection from removal and work authorization to nearly 700,000 unauthorized individuals who were brought to the United States as children" (pp. 9-10). The only thing that has stopped the Trump administration from terminating the DACA program are several federal court decisions from January 2018 to April 2018, ordering that DACA recipients continue to be protected by the program (pp. 9-10; also see McHugh, 2018: p. 1). Lind and Zarracina (2019) add that there are 200,000 American-born children with a DACA parent (also see Pierce et al., 2018a: p. 15).

On February 15, 2019, President Trump issued a proclamation:

"NOW, THEREFORE, I, DONALD J. TRUMP, by the authority vested in me by the Constitution and the laws of the United States of America, including sections 201 and 301 of the National Emergencies Act (50 U.S.C. 1601 et seq.), hereby declare that a national emergency exists at the southern border of the United States, and that section 12302 of title 10, United States Code, is invoked and made available, according to its terms, to the Secretaries of the military departments concerned, subject to the direction of the Secretary of Defense in the case of the Secretaries of the Army, Navy, and Air Force" (Presidential Proclamation on Declaring a National Emergency, 2019). 
According to Lind and Zarracina (2019), the average number of immigration related arrests, including immigrants without criminal records, by the Trump administration from February 2017 to September 2018, was 436 (139 without criminal records). In 2016, the figure was 300 (47 without criminal records). The average number of people in the U.S. Immigration and Customs Enforcement (ICE) Custody as of October 2018, was 44,631. In fiscal year 2016 (October 2015 to September 2016) the figure was 34,376. Lind and Zarracina (2019) also add that as of July 2018, there were 2737 immigrant children separated from their families by the federal government. In November 2018, there were 14,056 unaccompanied minors in the custody of the federal government. The monthly average in 2016 was 9000. As of September 14, 2018, the average length of stay in federal custody for unaccompanied minors before being place with a sponsor was 59 days. In 2016, the figure was 35 days.

In November 2017, the Trump administration ended Temporary Protected Status (TPS) for 2500 Nicaraguan and 59,000 Haitian immigrants living in the United States. In January 2018, the administration ended TPS for 200,000 immigrants from El Salvador living in the United States (The Trump Administration Agenda, 2018). According to Lind and Zarracina (2019), there are 273,000 American-born children with a TPS parent.

Klingner (2018) points out that the Trump administration threatened to "Cancel all federal funding to sanctuary states or cities (i.e., those with policies or laws that protect immigrants who are illegally in the United States from federal immigration law" (p. 4; also see Pierce \& Capps, 2017: p. 5; Pierce et al., 2018a: p. 12 \& 21). Pierce and Capps (2017) point out that the U.S. Department of Homeland Security and the U.S. Department of State will work together to refuse "... to grant visas to nationals of recalcitrant countries. The Secretary of State is directed to ensure that diplomatic efforts and negotiations with foreign states be contingent on the acceptance of their nationals subject to removal from the United States" (p. 7). Klingner (2018) points out that among the Trump administration's immigration priorities is: "Begin to deport 2 million illegal immigrant criminals and cancel visas to countries that do not accept their return, including those guilty of nothing more than traffic violations" (p. 4). Pierce et al. (2018a) add that: “... it does appear that the Trump administration has had some success in reducing the number of recalcitrant countries, meaning those that fail to cooperate or accept the return of their nationals from the United States." As of May 2, 2016, the total number of such countries was 23, "including Afghanistan, Algeria, the People's Republic of China, Cuba, Iran, Iraq, Libya, Somalia, and Zimbabwe" (p. 22).

Pierce and Capps (2017) point out that the Trump administration has authorized that "Federal agencies will not extend protections of the Privacy Act regarding personally identifiable information to individuals who are not citizens, including lawful permanent residents (LPRs, also known as green-card holders)" (p. 8). 


\section{Statistics on International Migration and Immigration to the United States}

The tables in this section present statistics on international migration and United States immigration. The international migration statistics show that the United States plays a key role in this phenomenon, especially as a host or destination nation. European nations and many Asian nations have also played a significant role in hosting international migrants. Almost all of the statistics on U.S. immigration show a significant decline in the number of non-immigrant and immigrant visa categories, including refugees from the last few yeas of the Barack Obama presidency to the Donald Trump presidency.

In 2000, there were 173 million international migrants (International Migration Report 2017, 2017: p. 4). Table 1 shows that by 2017, that figure increased to 257.8 million. Asia ranks at the top as a destination for international migrants: 79.6 million; Europe, 77.9 million; Northern America, 57.7 million; Africa, 24.7 million; Latin America and the Caribbean, 9.5 million; and Oceania, 8.4 million.

Table 2 presents the top 20 nations hosting international migrants in 2017. The twenty nations combined hosted 173.6 million immigrants, accounting for $67.3 \%$ of all international migrants. There are four nations with double figure numbers, with the United States leading all nations with 49.8 million migrants: Saudi Arabia and Germany each with 12.2 million; and Russia with 11.7 million. The United Kingdom, 8.8 million, the United Arab Emirates, 8.3 million, France and Canada each with 7.9 million, Australia, 7 million, and Spain and Italy each with 5.9 million, rounded out the top 11 host nations.

Table 3 presents the numbers of international migrants by region of origin in 2000 and 2017. In 2000, there were 65 million international migrants who originated from Asia. In 2017, that figure increased to 105.7 million; Europe, 49.6 million and 61.2 million respectively; Latin America and the Caribbean, 24.8 million and 37.7 million respectively; Africa, 21.6 million and 36.3 million respectively; Northern America, 3.2 million and 4.4 million respectively; and Oceania, 1.2 million and 1.9 million respectively. The overall figures are 165.4 million in 2000, and 247.2 million in 2017 (Table 3).

Table 1. Number of international migrants (millions) by region of destination, 2017.

\begin{tabular}{cc}
\hline Region & Number \\
\hline Africa & 24.7 \\
Asia & 79.6 \\
Europe & 77.9 \\
Northern America & 57.7 \\
Oceania & 8.4 \\
Latin America \& Caribbean & 9.5 \\
Total & $\mathbf{2 5 7 . 8}$
\end{tabular}

Source: International Migration Report 2017, 2017: p. 5. 
Table 2. Twenty countries or areas hosting the largest numbers of international migrants, 2017, number of migrants (millions).

\begin{tabular}{|c|c|}
\hline Country & Number \\
\hline United States & 49.8 \\
\hline Saudi Arabia & 12.2 \\
\hline Germany & 12.2 \\
\hline Russia & 11.7 \\
\hline United Kingdom & 8.8 \\
\hline United Arab Emirates & 8.3 \\
\hline France & 7.9 \\
\hline Canada & 7.9 \\
\hline Australia & 7.0 \\
\hline Spain & 5.9 \\
\hline Italy & 5.9 \\
\hline India & 5.2 \\
\hline Ukraine & 5.0 \\
\hline Turkey & 4.9 \\
\hline South Africa & 4.0 \\
\hline Kazakhstan & 3.6 \\
\hline Thailand & 3.6 \\
\hline Pakistan & 3.4 \\
\hline Jordan & 3.2 \\
\hline Kuwait & 3.1 \\
\hline Total & 173.6 \\
\hline$\%$ of all & 67.3 \\
\hline
\end{tabular}

Source: International Migration Report 2017, 2017: p. 6.

Table 3. Number of international migrants by region of origin, 2000 and 2017.

\begin{tabular}{ccc}
\hline Region & $\mathbf{2 0 0 0}$ & $\mathbf{2 0 1 7}$ \\
\hline Asia & 65 & 105.7 \\
Europe & 49.6 & 61.2 \\
Latin America \& Caribbean & 24.8 & 37.7 \\
Africa & 21.6 & 36.3 \\
Northern America & 3.2 & 4.4 \\
Oceania & 1.2 & 1.9 \\
Total & 165.4 & 247.2
\end{tabular}

Source: International Migration Report 2017, 2017: p. 10. 
Table 4 presents the twenty largest countries of origin of international migrants in 2017. The twenty nations of origin accounted for 126.3 million migrants, accounting for $51.1 \%$ of the total. Four nations have double figure numbers of migrants, with India leading the way, 16.6 million; Mexico, 13 million, Russia, 10.6 million, and China, 10 million. The following six nations rounded up the top 10: Bangladesh, 7.5 million, Syria, 6.9 million, Pakistan, 6 million, Ukraine, 5.9 million, the Philippines, 5.7 million, and the United Kingdom, 4.9 million.

Table 5 presents statistics on immigrant and non-immigrant visas issued at United States foreign service posts for fiscal years 2014 to 2018. The table shows that there is a decline in all categories for both immigrant and non-immigrants visas from the Obama administration to the Trump administration. For example, the total immigrant visas issued in 2016, the last full year of the Obama administration was 617,752 . It declined to 559,536 in 2017, and declined again to 533,557 in 2018, the first full year of the Trump administration. For non-immigrant visas, the figures were 10,381,491 in 2016 and 9,028,026 in 2018.

Table 4. Twenty largest countries or areas of origin of international migrants, 2017, number of migrants (millions).

\begin{tabular}{|c|c|}
\hline Country & Number \\
\hline India & 16.6 \\
\hline Mexico & 13.0 \\
\hline Russia & 10.6 \\
\hline China & 10.0 \\
\hline Bangladesh & 7.5 \\
\hline Syria & 6.9 \\
\hline Pakistan & 6.0 \\
\hline Ukraine & 5.9 \\
\hline Philippines & 5.7 \\
\hline United Kingdom & 4.9 \\
\hline Afghanistan & 4.8 \\
\hline Poland & 4.7 \\
\hline Indonesia & 4.2 \\
\hline Germany & 4.2 \\
\hline Kazakhstan & 4.1 \\
\hline Palestine & 3.8 \\
\hline Romania & 3.6 \\
\hline Turkey & 3.4 \\
\hline Egypt & 3.4 \\
\hline Italy & 3.0 \\
\hline Total & 126.3 \\
\hline
\end{tabular}

Source: International Migration Report 2017, 2017: p. 13. 
Table 5. Immigrant and Nonimmigrant Visas Issued at U.S. Foreign Service Posts Fiscal Years 2014-2018.

\begin{tabular}{cccccc}
\hline Immigrant Categories & $\mathbf{2 0 1 4}$ & $\mathbf{2 0 1 5}$ & $\mathbf{2 0 1 6}$ & $\mathbf{2 0 1 7}$ & $\mathbf{2 0 1 8}$ \\
\hline Immediate Relatives & 185,130 & 243,432 & 315,352 & 254,430 & 236,526 \\
Special Immigrants1 & 12,084 & 9468 & 16,176 & 20,034 & 9375 \\
Vietnam Amerasian Immigrants & 13 & 13 & 6 & 36 & 92 \\
Family Sponsored Preference & 197,760 & 208,840 & 215,498 & 212,155 & 211,641 \\
Employment-Based Preference & 21,365 & 21,613 & 25,056 & 23,814 & 27,345 \\
Armed Forces Special Immigrants & $\mathbf{0}$ & $\mathbf{0}$ & $\mathbf{0}$ & $\mathbf{0}$ & $\mathbf{0}$ \\
Diversity Immigrants & 51,018 & 48,097 & 45,664 & 49,067 & 48,578 \\
Total & 467,370 & 531,463 & 617,752 & 559,536 & 533,557 \\
Nonimmigrant Categories & & & & & \\
Visas Issued & $9,932,480$ & $10,891,745$ & $10,381,491$ & $9,681,913$ & $9,028,026$ \\
Total & {$[1,232,884]$} & {$[1,203,876]$} & {$[1,106,723]$} & {$[1,073,915]$} & {$[1,032,467]$} \\
(B1/B2/Border Crossing Cards)2 & $9,932,480$ & $\mathbf{1 0 , 8 9 1 , 7 4 5}$ & $10,381,491$ & $\mathbf{9 , 6 8 1 , 9 1 3}$ & $\mathbf{9 , 0 2 8 , 0 2 6}$ \\
\hline
\end{tabular}

Source: Table 1. Immigrant and Nonimmigrant Visas Issued at U.S. Foreign Service Posts, U.S. State Department, 2019. Note: The totals on this table do not include replaced immigrant visas. 1 Special Immigrant totals include returning residents, Iraqi and Afghan translators, certain Iraqis or Afghans employed by or on behalf of the U.S. Government, and certain family members of U1 Nonimmigrants. 2 Combination B1/B2 visitor visa/Border Crossing Cards are issued to Mexican nationals. B1/B2/Border Crossing Card issuances are included in the "Visas Issued" line.

Table 6 presents the number of investor visas issued by the U.S. State Department each year from 2014 to 2018 . An applicant must invest $\$ 500,000$ to one million dollars to be eligible for this category of visas. Table 6 shows that the figures dropped each year from 9130 in 2014, to 8692 in 2015, to 8,043 in 2016, to 8000 in 2017, and finally 7468 in 2018.

Table 7 presents the numbers of diversity lottery visas issued from 2015 to 2018. The figures show that this is the only visa program that has remained about the same from 2015 to 2018. In fact, the figures increased from 49,377 in 2015, to 49,976 in 2017, and dropped to 49,713 in 2018.

Table 8 presents the numbers of refugees resettled in the United States from 2015 to 2018. According to Shacknove (1985), a refugee is “ ... is a person fleeing life-threating conditions" (p. 274). According to Cepla (2019), the President of the United States determines the number of refugees accepted to the United States annually, with consultation with the United States Congress. Table 8 shows that the overall refugee figures declined from a high of 96,874 in 2016, the last full year of the Obama administration to 22,874 in 2018 , the first full year of the Trump administration. Table 8 substantiates President Donald Trump's publicly stated preference for European immigrants, with Europe being the only region that experienced an increase in refugees to the United States from 2015 to 2018. According to Table 8, in 2015, the total number of refugees from Europe accepted into the United States was 2415. In 
Table 6. Investor visas issued at U.S. Foreign service posts, Fiscal Years 2014-2018.

\begin{tabular}{cccccc}
\hline Employment Category & 2014 & 2015 & 2016 & 2017 & 2018 \\
\hline $\begin{array}{c}\text { Investor pilot program in targeted } \\
\text { area, spouse and children }\end{array}$ & 9130 & 8692 & 8043 & 8000 & 7468 \\
\hline
\end{tabular}

Source: Table II Fiscal Years 2014-2018 Classes of Immigrants Issued Visas at Foreign Service Posts, 2019. U.S. State Department.

Table 7. Immigrant number use for visa issuances and adjustments of status in the diversity (lottery) immigrant category fiscal years 2015-2018.

\begin{tabular}{ccccc}
\hline Region & $\mathbf{2 0 1 5}$ & $\mathbf{2 0 1 6}$ & $\mathbf{2 0 1 7}$ & $\mathbf{2 0 1 8}$ \\
\hline Africa & 19,686 & 20,706 & 19,211 & 20,532 \\
Asia & 7570 & 8898 & 7650 & 6290 \\
Europe & 19,811 & 15,207 & 20,516 & 20,434 \\
North America & 7 & 5 & 3 & 2 \\
Oceania & 844 & 532 & 766 & 824 \\
Latin America \& Caribbean & 1459 & 1370 & 1830 & 1631 \\
Grand Totals & 49,377 & 46,718 & 49,976 & 49,713 \\
\hline
\end{tabular}

Source: Table VII Immigrant Number Use for Visa Issuances and Adjustments of Status in the Diversity Immigrant Category, 2019. U.S. Department of State.

Table 8. Refugees resettled in the United States by world region, 2015 to 2018.

\begin{tabular}{|c|c|c|c|c|}
\hline Africa & 2015 & 2016 & 2017 & 2018 \\
\hline \multicolumn{5}{|l|}{ Northern Africa } \\
\hline Algeria & 0 & 0 & 0 & 2 \\
\hline Egypt & 11 & 27 & 3 & 1 \\
\hline Libya & 0 & 4 & 0 & 1 \\
\hline Morocco & 0 & 2 & 0 & 0 \\
\hline Sudan & 1688 & 1479 & 652 & 85 \\
\hline Tunisia & 7 & 2 & 1 & 0 \\
\hline Total & 1706 & 1514 & 656 & 89 \\
\hline \multicolumn{5}{|l|}{ Eastern Africa } \\
\hline Burundi & 1208 & 777 & 136 & 260 \\
\hline Djibouti & 2 & 2 & 2 & 1 \\
\hline Eritrea & 1783 & 2011 & 1868 & 1340 \\
\hline Ethiopia & 682 & 1322 & 450 & 346 \\
\hline Kenya & 2 & 6 & 5 & 14 \\
\hline Republic of South Sudan & 113 & 221 & 107 & 2 \\
\hline Rwanda & 197 & 150 & 74 & 157 \\
\hline Somalia & 7779 & 10,786 & 2770 & 139 \\
\hline Tanzania & 0 & 1 & 1 & 0 \\
\hline
\end{tabular}




\section{Continued}

\begin{tabular}{ccccc}
\hline Uganda & 66 & 71 & 44 & 46 \\
Zambia & 0 & 1 & 1 & 0 \\
Zimbabwe & 5 & 11 & 5 & 10 \\
Total & 11,837 & 15,359 & 5463 & 2315
\end{tabular}

Middle Africa

$\begin{array}{ccccc}\text { Angola } & 5 & 3 & 0 & 1 \\ \text { Cameroon } & 8 & 18 & 17 & 18 \\ \text { Central African Republic } & 108 & 555 & 104 & 150 \\ \text { Chad } & 6 & 7 & 3 & 0 \\ \text { Congo } & 22 & 16 & 4 & 7 \\ \text { Dem. Rep. Congo } & 8206 & 19,829 & 5352 & 9305 \\ \text { Equatorial Guinea } & 2 & 0 & 0 & 0 \\ \text { Gabon } & 0 & 2 & 0 & 0 \\ \text { Total } & 8357 & 20,430 & 5480 & 9481\end{array}$

Southern Africa

$\begin{array}{ccccc}\text { Botswana } & 0 & 0 & 1 & 0 \\ \text { Namibia } & 1 & 0 & 0 & 0 \\ \text { South Africa } & 2 & 0 & 0 & 1 \\ \text { Total } & 3 & 0 & 1 & 1\end{array}$

\section{Western Africa}

$\begin{array}{ccccc}\text { Burkina Faso } & 0 & 1 & 1 & 0 \\ \text { Gambia } & 3 & 5 & 0 & 0 \\ \text { Ghana } & 0 & 0 & 3 & 3 \\ \text { Guinea } & 2 & 5 & 7 & 10 \\ \text { Ivory Coast } & 41 & 65 & 48 & 14 \\ \text { Liberia } & 11 & 19 & 5 & 6 \\ \text { Mali } & 8 & 4 & 4 & 0 \\ \text { Niger } & 0 & 0 & 0 & 2 \\ \text { Nigeria } & 3 & 7 & 2 & 1 \\ \text { Senegal } & 7 & 27 & 10 & 14 \\ \text { Sierra Leone } & 2 & 5 & 3 & 0 \\ \text { Togo } & 5 & 14 & 1 & 1 \\ \text { Total } & 82 & 152 & 84 & 51 \\ \text { Africa Total } & 21,985 & 37,455 & 11,684 & 11,937\end{array}$

Latin America \& Caribbean

Caribbean

\begin{tabular}{ccccc} 
Cuba & 1060 & 351 & 87 & 0 \\
Jamaica & 1 & 1 & 0 & 1 \\
Total & 1061 & 352 & 87 & 1 \\
\hline
\end{tabular}




\section{Continued}

\section{Central America}

El Salvador

Guatemala

Honduras

Total

South America

Colombia
Ecuador
Total

Latin America

\& Caribbean Total

1185

939

\section{Asia}

\section{Central Asia}

Kazakhstan

Kyrgyzstan

Tajikistan

Turkmenistan

Uzbekistan

Total

Eastern Asia

$$
\text { China* }
$$

Korea, North

Mongolia

Total

\section{Southern Asia}

Afghanistan
Bangladesh
Bhutan
India
Iran
Nepal
Pakistan
Sri Lanka

Total

South-eastern Asia

Burma

683
48
71
802




\section{Continued}

\begin{tabular}{|c|c|c|c|c|}
\hline Indonesia & 9 & 1 & 2 & 0 \\
\hline Laos & 0 & 7 & 0 & 0 \\
\hline Malaysia & 1 & 3 & 0 & 0 \\
\hline Philippines & 0 & 2 & 1 & 0 \\
\hline Thailand & 3 & 3 & 3 & 0 \\
\hline Vietnam & 39 & 57 & 52 & 94 \\
\hline Total & 17,536 & 11,662 & 3783 & 3865 \\
\hline \multicolumn{5}{|l|}{ Western Asia } \\
\hline Armenia & 31 & 64 & 61 & 32 \\
\hline Azerbaijan & 19 & 39 & 6 & 2 \\
\hline Georgia & 12 & 11 & 0 & 1 \\
\hline Iraq & 10,169 & 11,332 & 3339 & 91 \\
\hline Israel & 0 & 0 & 0 & 1 \\
\hline Jordan & 4 & 6 & 3 & 1 \\
\hline Kuwait & 2 & 6 & 1 & 1 \\
\hline Oman & 0 & 0 & 1 & 0 \\
\hline Palestine & 79 & 71 & 51 & 0 \\
\hline Saudi Arabia & 5 & 0 & 0 & 1 \\
\hline Syria & 2,192 & 15,479 & 3024 & 41 \\
\hline Turkey & 2 & 0 & 1 & 0 \\
\hline United Arab Emirates & 0 & 1 & 0 & 0 \\
\hline Yemen & 8 & 27 & 17 & 3 \\
\hline Total & 12,523 & 27,036 & 6504 & 174 \\
\hline Asia Total & 40,611 & 52,746 & 16,672 & 6273 \\
\hline \multicolumn{5}{|l|}{ Europe } \\
\hline \multicolumn{5}{|l|}{ Eastern Europe } \\
\hline Belarus & 102 & 187 & 99 & 169 \\
\hline Moldova & 259 & 550 & 266 & 127 \\
\hline Russia & 292 & 527 & 367 & 328 \\
\hline Ukraine & 1760 & 3642 & 3089 & 3101 \\
\hline Total & 2413 & 4906 & 3821 & 3725 \\
\hline
\end{tabular}

Northern Europe

$\begin{array}{ccccc}\text { Latvia } & 0 & 8 & 0 & 0 \\ \text { Norway } & 0 & 2 & 0 & 0 \\ \text { Sweden } & 0 & 2 & 1 & 0 \\ \text { Total } & 0 & 12 & 1 & 0\end{array}$

Southern Europe$$
\text { Croatia }
$$

1

2

0

0 


\section{Continued}

\begin{tabular}{ccccc}
\hline Serbia & 0 & 2 & 0 & 0 \\
Total & 1 & 4 & 0 & 0 \\
Western Europe & & & & \\
Belgium & 0 & 2 & 0 & 0 \\
Netherlands & 1 & 0 & 0 & 0 \\
Total & 1 & 2 & 0 & 0 \\
Europe Total & 2415 & 4924 & 3822 & 3725 \\
Oceania & & & & 0 \\
New Zealand & 0 & 0 & 5 & $\mathbf{2 2 , 8 7 4}$ \\
Grand Totals & 66,517 & $\mathbf{9 6 , 8 7 4}$ & $\mathbf{3 3 , 3 6 8}$ & \\
\hline
\end{tabular}

Source: Admissions \& Arrivals, 2019. Refugee Processing Center.

2018, that figure increased to 3725. The figures for Africa were 21,985 in 2015 and 11,937 in 2018; for Latin America and the Caribbean, the figures were 1506 in 2015 and 939 in 2018; for Asia, the figures were 40,611 in 2015 and 6273 in 2018 (also see Cepla, 2019).

Table 9 presents the number of green cards issued to immigrants in the United States each year from 2015 to 2018. Table 9 shows that the figures dropped from 2016, the last year of the Obama administration to 2018, the first full year of the Trump administration: 565,427 adjustment of status and 618,078 new arrivals in 2016, to 428,990 adjustment of status and 391,758 for new arrivals in 2018.

Table 10 presents the number of people who became naturalized U.S. citizens from 2014 to 2017. Table 10 shows that the figures increased from 2014 to 2016 (Obama years): 653,416; 703,259; and 753,060. However, the total declined in 2017 (the first year of Trump administration) to 707,265.

Table 11 presents international students enrolled in U.S. colleges and universities for 2015-2016, 2016-2017 and 2017-2018 academic years. According to Table 11, the figures are lower during the first full academic year of Trump, 2017-2018 (891,330) than 2015-2016 (896,341) and 2016-2017 $(903,127)$ academic years.

Tables 5-11 illustrate that there is a visible decline in immigration into the United States from the last few years of the Barack Obama administration to the first two years of the Donald Trump administration. Other reports have also substantiated this development (Clarke, 2019; Davis \& Shear, 2019; Felter \& Renwick, 2019; Ibe, 2019).

\section{Implications of the Trump Administration's Immigration Policies}

Scholars and activists have presented a number of mostly interrelated implications of the Trump administration's immigration measures. Among the implications of the Trump administration's immigration policies are: loss of talented or 
Table 9. Permanent resident (Green) Cards Issued by the U.S. Department of Homeland Security, 2015 to 2018.

\begin{tabular}{|c|c|c|c|c|c|c|c|c|}
\hline & \multicolumn{2}{|c|}{2015} & \multicolumn{2}{|c|}{2016} & \multicolumn{2}{|c|}{2017} & \multicolumn{2}{|c|}{2018} \\
\hline & $\begin{array}{c}\text { Adjustments } \\
\text { of Status }\end{array}$ & $\begin{array}{c}\text { New } \\
\text { Arrivals }\end{array}$ & $\begin{array}{c}\text { Adjustments } \\
\text { of Status }\end{array}$ & $\begin{array}{c}\text { New } \\
\text { Arrivals }\end{array}$ & $\begin{array}{c}\text { Adjustments } \\
\text { of Status }\end{array}$ & $\begin{array}{c}\text { New } \\
\text { Arrivals }\end{array}$ & $\begin{array}{c}\text { Adjustments } \\
\text { of Status }\end{array}$ & $\begin{array}{c}\text { New } \\
\text { Arrivals }\end{array}$ \\
\hline Total & 542,315 & 508,716 & 565,427 & 618,078 & 549,086 & 578,081 & 428,990 & 391,758 \\
\hline Africa & 50,465 & 50,950 & 50,111 & 63,315 & 50,756 & 68,068 & 41,210 & 42,382 \\
\hline Asia & 210,034 & 209,263 & 203,099 & 259,200 & 190,910 & 233,833 & 152,475 & 151,293 \\
\hline Europe & 54,306 & 31,497 & 57,947 & 35,620 & 53,129 & 31,585 & 38,920 & 21,592 \\
\hline North America & 181,655 & 184,471 & 203,648 & 223,645 & 203,734 & 209,565 & 160,568 & 149,783 \\
\hline Oceania & 3320 & 2084 & 3481 & 2107 & 3293 & 1750 & 2154 & 1315 \\
\hline South America & 42,250 & 30,059 & 46,775 & 32,833 & 46,904 & 32,172 & 33,520 & 24,806 \\
\hline Unknown & 285 & 392 & 366 & 1358 & 360 & 1108 & 143 & 587 \\
\hline
\end{tabular}

Source: Yearbook of Immigration Statistics, 2019. U.S. Department of Homeland Security.

Table 10. Number of people naturalized in the United States, 2014 to 2017.

\begin{tabular}{ccccccc}
\hline \multirow{2}{*}{ Year } & Petitions & \multicolumn{5}{c}{ Persons naturalized } \\
\cline { 2 - 7 } & filed & Total & Civilian & Military $^{2}$ & Not reported & denied \\
\hline 2014 & 773,824 & 653,416 & 642,431 & 7468 & 3517 & 66,767 \\
2015 & 783,062 & 730,259 & 720,645 & 7234 & 2380 & 75,810 \\
2016 & 972,151 & 753,060 & 742,090 & 8885 & 2085 & 86,033 \\
2017 & 986,851 & 707,265 & 695,718 & 6883 & 4664 & 83,176 \\
\hline
\end{tabular}

Source: Yearbook of Immigration Statistics, 2019. U.S. Department of Homeland Security.

Table 11. International student and U.S. higher education enrollment, 2015/16-2017/18.

\begin{tabular}{ccccccc}
\hline Year & $\begin{array}{c}\text { Enrolled } \\
\text { Int'l Students }\end{array}$ & $\begin{array}{c}\text { Optional } \\
\text { Practical } \\
\text { Training (OPT) }\end{array}$ & $\begin{array}{c}\text { Total Int'l } \\
\text { Students }\end{array}$ & $\begin{array}{c}\text { Annual } \\
\text { \% Change }\end{array}$ & $\begin{array}{c}\text { Total U.S. } \\
\text { Enrollment* }\end{array}$ & $\begin{array}{c}\% \\
\text { Int'l }\end{array}$ \\
\hline $2015 / 16$ & 896,341 & 147,498 & $1,043,839$ & 7.1 & $20,264,000$ & 5.2 \\
$2016 / 17$ & 903,127 & 175,695 & $1,078,822$ & 3.4 & $20,185,000$ & 5.3 \\
$2017 / 18$ & 891,330 & 203,462 & $1,094,792$ & 1.5 & $19,831,000$ & 5.5 \\
\hline
\end{tabular}

Source: Enrollment Trends: International Student Data, 2019.

highly skilled professionals; loss of employers; loss of tax payers and tax revenues; increase in negative opinions of the American government and society; reduction in the number of immigrants in the country; increase in crime rates; division within the American society; lack of cooperation with the United States in international politics and relations; loss of prestige of the United States in the international arena; and the slow growth or stagnation of the population of the United States (Batalova \& Fix, 2017; Bose 2018; Cervantes \& Walker, 2017; Gubernskaya \& Dreby, 2017; Heyer, 2018; Hill \& Wiehe, 2017; Kaba, 2017a; Khullar et al., 2017; Latinos \& the New Trump Administration, 2017; Mayda \& Peri, 
2017; McHugh, 2018; Patel \& Levinson-Waldman, 2017; Pierce et al., 2018b; Rose-Redwood \& Rose-Redwood, 2017; Table 19: Doctorate recipients, by ethnicity, race, and citizenship, 2019; Table 53: Doctorate recipients with temporary visas intending to stay, 2019; Wood, 2018).

\section{Loss of Talented or Highly Skilled Immigrants}

It has been noted that one negative implication of the Trump administration's immigration policies is the loss of talented or highly skilled immigrants. While Trump has attempted to claim that immigrants take jobs away from American citizens, that they are less educated, and that they are a burden on the American society, the evidence reveals those claims not to be the case. Immigrants are among the most educated people in the United States. According to Batalova and Fix (2017), new immigrants to the United States have substantially increased their human capital (educational attainment or specialized skills). Immigrants to the United States, especially those who have arrived recently tend to have more college degrees than those of the past. "The size of the college-educated immigrant population more than tripled between 1990 and 2015, from 3.1 million to 11.1 million" (pp. 2-3). The authors add that the proportion of college graduates among all immigrant adults increased from $20 \%$ in 1990 to $30 \%$ in 2015 . In 1990 , immigrant adults accounted for $10 \%$ of college-educated adults in the United States. By 2015, that figure increased to $17 \%$ of 66.4 million college-educated adults in the country, three percentage points higher than the immigrant population of the United States (almost 14\%). The proportion of immigrants who arrived in the United States after 2010 with a university degree is $48 \%$, substantially higher than the $27 \%$ of immigrants who arrived from 1986 to 1990 (Batalova \& Fix, 2017: pp. 2-3; also Kaba, 2004: pp. 22-24; Mazrui \& Kaba, 2016: pp. 87-93; Rose-Redwood \& Rose-Redwood, 2017: pp. 1-5).

Khullar et al. (2017) point out that foreign medical graduates accounted for $164,111(21.1 \%)$ of the 778,781 physicians practicing in the United States in 2015. They accounted for 15,075 (18.3\%) of the 82,737 academic physicians in the country. They accounted for 2,808 (15.1\%) of the academic physicians who are full professors in the United States. Foreign medical graduates accounted for $18 \%$ of all publications by physicians practicing in the United States, including $18.5 \%$ of first-authored publications. They also accounted for 1526 (12.5\%) of 12,155 National Institutes of Health (NIH) grants earned by physicians practicing in the United States, and led 2276 (18.5\%) of 12,324 clinical trials (Khullar et al., 2017: pp. 584-585).

Immigrants who earned their terminal degrees from colleges and universities in the United States tend to prefer to remain in the country instead of going to their homelands or somewhere else. This is the case even after Donald Trump became president or his administration's tough immigration measures. For example, in 2014, of the 53,992 doctoral degree recipients from higher education institutions in the United States, 34,005 (63\%) were citizens and permanent residents, and 15,839 (29.3\%) were temporary visa holders. Of the 54,664 doctoral 
degree recipients in 2017 in the United States, 35,791 (65.5\%) were citizens and permanent residents, and 16,323 (30\%) were temporary residents (Table 19: Doctorate recipients, by ethnicity, race, and citizenship status, 2019). In 2015, of 16,130 temporary visa holders who earned doctoral degrees in the United States, $71.3 \%$ said that they intended to stay in the country. In 2017, of the 16,323 temporary visa holders who earned doctoral degrees in the United States, $74.2 \%$ said that they intended to stay in the country (Table 53: Doctorate recipients with temporary visas intending to stay, 2019). It is also useful to note that it is the American society through its colleges and universities that actually financially supports the education of a substantial number of international students earning their terminal degrees in the country. For example, of 48,072 doctoral degree recipients in the United States in 2017, 32,472 were citizens and permanent residents. Of the 32,472 graduates who were citizens and permanent residents, $26.3 \%$ had research assistantships or traineeships. Of 15,436 temporary visa holders, $47.9 \%$ had research assistantships or traineeships (TABLE 35 Doctorate recipients' primary source of financial support, by broad field of study, sex, citizenship status, ethnicity, and race: 2017, 2019; Kaba, 2017b: pp. 174-181).

Kaba (2017a) examines Carnegie Corporation's “Great Immigrants” honorees from 2006 to 2015. These are prominent immigrants in the United States who have naturalized. Of the 408 honorees, 24 (5.9\%) were Nobel laureates by 2015, and they won their Nobel prize while in the United States. Of the 408 honorees, $323(79.2 \%)$ had earned 352 terminal or highest degrees, including $129(36.7 \%$ of 352 total degrees) doctoral degrees; 92 (26.1\%) master's degrees; 76 (21.6\%) bachelor's degrees; 30 (8.5\%) Juris Doctor (JD) degrees; and 21 (6\%) doctor of medicine (MD) degrees (Kaba, 2012: pp. 47-48).

The current Trump administration's immigration policies could result in the decline in the numbers of these talented or highly skilled immigrants. If these immigrants come to believe that they are not appreciated or that they are treated as scapegoats for the challenges facing the American society, many might decide to relocate to other countries. For example, Canada is reported to be one of the developed countries currently benefiting from the loss of skilled immigrants leaving the United States as a result of the Trump administration's immigration policies. El-Bawab (2019) reports that: "Many students and skilled immigrants looking for a backup plan are heading to Canada, where it's much easier to stay and work, lawyers say." Molla (2019) also reports that the Trump administration's immigration policies have resulted in Canada becoming a major tech hub in the world. “... Canada has become a major tech hub. Toronto ranked No. 4 last year on [Coldwell Banker Richard Ellis] CBRE's tech talent list. That put it just behind San Francisco, Seattle, and Washington, DC, as a top location for tech workers." Molla (2019) claims that: "Kollol Das, a former electronic engineer and gaming startup founder from India who now specializes in machine learning, was offered two high-skilled tech jobs last fall, one based in New York and one based in Toronto." Das selected Toronto over New York because of their favorable skilled immigration policies. 


\section{Economic Contributions of Immigrants to the U.S. Economy}

Immigrants make substantial economic contributions to the economy of the United States. The United Stated would never have been the leading economic nation in the world without the contributions of immigrants. According to $\mathrm{Gu}-$ bernskaya and Dreby (2017): "A recent comprehensive report concluded that immigration has overall positive impact on the US economy ..." (p. 417). Mayda and Peri (2017) point to research that claims that substantial evidence illustrates that immigrant scientists and engineers make important contributions to the country's innovation and their productivity in the local communities where they reside, benefit significantly from them being there. Within companies in the United States, high-skilled immigrant Science, Technology, Engineering and Mathematics (STEM) workers tend to complement their native-born counterparts, especially young workers. Immigrant workers make substantial contributions to the growth and productivity of the United States economy. The authors also note that "... a reduction in high-skilled immigrants is likely to reduce-rather than to increase opportunities,-productivity and wages of the native-born American workforce, especially for the college educated" (pp. 71-72).

Khullar et al. (2017) point out that foreign medical graduates in the United States, who accounted for almost one out of every four of the physician workforce tend to practice in large numbers in underserved communities, and that they are also in specialties that have a shortage. They account for over half of those holding internal medicine positions and their patients "have mortality rates similar to, if not lower than, those cared for by U.S. graduates. Some states and hospitals rely heavily on physicians in the H-1B visa program" (p. 584; also see Maurer, 2018; Stone \& Bryant, 2018/2019).

Kaba's (2017a) study of Carnegie Corporation's “Great Immigrants” honorees found that of the 408 honorees, 122 (30\%) had a net worth of $\$ 113.4$ billion (p. 142). This means that these immigrants are important tax-payers and employers in the United States. According to Hill and Wiehe (2017), the young immigrants enrolled in DACA contribute an estimated $\$ 1.7$ billion to state and local taxes, including "personal income, property, and sales and excise taxes" (pp. 1-2). The concern is for the United States not to experience the type of brain drain that many developing nations and some developed nations such as the United Kingdom, Germany, Australia, and Canada have experienced in the past two decades (Kaba, 2017a: pp. 40-46). According to Mayda and Peri (2017), the Trump administration's immigration policies could establish an environment seen as hostile to new immigrants not open to immigrant workers, including those with high levels of education or specialized skills. The authors note that: "This could divert the highly and internationally mobile scientists, engineers and professionals towards countries such as Canada, Australia and China, eroding the US excellence in their areas, which is a pillar of US economic leadership" (p. 73; also see Treyz \& Evangelakis, 2018). 


\section{Immigrants Commit Fewer Crimes in the United States}

Many scholars have produced research illustrating that immigrants in the United States tend to commit fewer crimes compared to their native-born counterparts. As a result, proportionally, fewer immigrants are incarcerated than their native-born counterparts. For example, Heyer (2018) points out that when he became president, Donald Trump's early immigration measure was to make the country "Safe Again" coming from his "... law and order mantle he adopted to distinguish his candidacy. This framework casts unauthorized immigrants as willful lawbreakers, posing national security threats. Yet recent studies indicate higher rates of immigration correlate with lower rates of violent and property crime" (p. 150). According to Landgrave and Nowrasteh (2019), as of 2017, there were 1,926,390 native-born Americans, 106,431 undocumented immigrants, and 52,424 legal immigrants incarcerated in jails and prisons across the United States. On a per capita basis, more native-born Americans were in jails and prisons in 2017 than both legal immigrants or undocumented immigrants: 1471 per 100,000 of their population; 756 per 100,000 for undocumented immigrants; and 364 per 100,000 for legal immigrants. The authors add that, "Illegal immigrants are 49 percent less likely to be incarcerated than native-born Americans. Legal immigrants are 75 percent less likely to be incarcerated than natives" (pp. 2-3).

\section{Reduction in Respect and Recognition of the Trump Administration Nationally and Internationally}

Regardless of their political party or philosophy, it is always important for the leadership of any presidential administration in the United States not to push the masses to a point where they feel the need to push back or fight back. The reason is that people across the world are also likely to do the same by showing less respect or recognition for that presidential administration. McHugh (2018) explains how some state and local governments are resisting federal immigration orders and the potential implications, especially as they relate to state and local law enforcement, refugee resettlement, elementary and secondary education, higher education, and health and social services (pp. 2-8). Kocher (2017) points out that immigrant rights groups are challenging the Trump administration's immigration orders using three strategies: “... sanctuary city policy, rapid response teams, and the creation of a community advocate for families in removal proceedings" (p. 167). Although these three strategies are different, “... each strategy was motivated by a well-founded fear of an imminent increase in ICE activity that would likely result in high numbers of arrests, detentions, and deportations" (pp. 167-168; Enriquez et al., 2019; Reich, 2018).

Internationally, public opinion polls show that the Trump administration and to some extent the United States are experiencing reduction in respect, recognition, and cooperation, especially from nations that once stood with the United States, including providing material support, military troops, moral support, and 
other support to U.S. activities across the world. For example, an October 1, 2018, international public opinion poll released by the Pew Research Center shows that while the United States has relatively high favorability ratings in many developing and some developed nations such as the Philippines (83\%); South Korea (80\%); Kenya (70\%); Japan (67\%); Nigeria (62\%); and Australia (54\%), the figures are lower in countries that were once strong allies of the United States: Canada (39\%), France (38\%), the Netherlands (34\%), Mexico (32\%), and Germany (30\%). In 2018, 43\% of people in the United Kingdom, $40 \%$ in France, 35\% in Germany, and 31\% in Spain said that the United States "respects its people's personal freedoms". In 2008, those figures were $70 \%$ in Germany, 69\% in the United Kingdom, 65\% in France, and 49\% in Spain. Of 25 countries across the world surveyed in 2018, a median of $70 \%$ said that the United States does not take their country's interests into account, and a median of $70 \%$ said that they have no confidence in President Donald Trump: $93 \%$ in Spain, 91\% in Mexico, 90\% each in Germany and France, 82\% in Sweden, 81\% in the Netherlands, $78 \%$ in Brazil, $75 \%$ in Canada, 70\% each in Italy and the United Kingdom, 66\% each in Australia and Japan, 54\% in South Korea, 49\% in South Africa, 29\% in Nigeria, and 18\% in the Philippines (Wike et al., 2018: p. 6, 10, 28 \& 32; M'Cormack-Hale \& Kaba, 2015).

\section{Stagnation or Decline of the Population of the United States}

The Trump administration's immigration policies also have the potential to cause a stagnation or decline of the population of the United States. This is especially the case as the United States has stopped meeting its population's natural replacement level of 2.1 children born per woman. The fertility rate (number of children born to the average woman) in the United States was 1.87 in 2017 and the world average in 2018 was 2.42. The United Nations recommends 2.1 children born per woman to sustain a society's population or else it would need immigration to increase its population. The population growth rate in the United States was $0.8 \%$ in 2018 and the world average in 2018 was 1.05 . This also means that the United States actually needs more immigration not less. This means that the United States might start losing important taxpayers, especially as it faces challenges in continuing to provide services to the elderly population. Of the 329.3 million people in the United States in 2018, 16.03\% were 65 years and over (CIA World Factbook, 2019).

\section{Undermining Decades Long Efforts by Refugee Resettlement Agencies}

The Trump administration's decision to substantially reduce the number of refugees accepted to the United States undermines the important work that many religious and civic organizations have done to resettle refugees across the country in the past several decades. According to Young (2017), “... the United States 
had begun welcoming refugees after the Displaced Persons Act of 1948 (although Congress only standardized the placement of refugees after 1980, with the Refugee Act of 1980)" (p. 226). These religious and civic organizations known as voluntary agencies or VOLAGs, work with the United States government and the United Nations to resettle refugees across the United States. Among their activities are: "... they operate field offices as satellites while in others they subcontract with local immigration organizations or social service providers. Cities, states, and counties are also part of the complex system that governs resettlement. Some states, for example, have extensive offices dedicated to refugee services and an official State Refugee Coordinator, while in others resettlement agency staff fulfill this statewide coordinating role." The voluntary agencies that help refugees resettle across the United States include: Church World Service (CWS); Episcopal Migration Ministries (EMM); Ethiopian Community Development Council (ECDC); Hebrew Immigrant Aid Society (HIAS); International Rescue Committee (IRC); Lutheran Immigration and Refugee Service (LIRS); U.S. Committee for Refugees and Immigrants (USCRI); United States Conference of Catholic Bishops (USCCB); and World Relief (WR) (Young, 2017: p. 322).

\section{Impact of Family Separation}

The Trump administration's family separation policy has been one of the most sensitive and harmful to both legal and undocumented immigrants. The deportation of parents of American citizens, detention of children seeking asylum who are separated from their parents, and the decline in the number of visas for family reunification are all having a big impact on Immigrants, their families and supporters. Hill and Wiehe (2017) point out that since becoming president of the United States, Donald Trump's immigration measures have separated: “... families and removed established members of communities. The administration's disregard for the contributions of immigrants, regardless of their legal status, is of real concern for young immigrants whose parents brought them to the United States as children” (p. 1). According to Cervantes and Walker (2017):

"Family separation is by far the most damaging effect of Trump's aggressive policies. Research demonstrates the critical influence parents have in their child's overall development and future success, meaning that the sudden loss of a parent can significantly harm long-term outcomes. Parents facing deportation must also make the difficult decision whether to bring their child with them-often to a country their child has never known-or leave them behind in the care of a family member or other trusted guardian. Both outcomes present unique challenges to child wellbeing. In some cases, children may unnecessarily enter the child welfare system, a scenario that can have particularly dire consequences, including the possible termination of parental rights" (p. 3; also see Roth et al., 2018). 
According to a February 23, 2017, Pew Research Center report, 41\% of Latinos said that they "Have serious concerns about [their] place in America." The figures were 55\% for Latinos without citizenship or green card and 49\% for Latinos who are green card holders (p. 4). Pierce et al. (2018b) note that the frequent tough rhetoric about immigration in the United States and the ongoing changes to the nation's immigration system have negatively impacted how people behave in the United States and abroad. In the United States, because immigrant communities have become so fearful and staying "under the radar" during the Trump presidency, reports have claimed “... a dip in crime reporting, including on domestic violence; fewer applications for public benefits to which immigrants or their U.S.-born children are entitled; and rising no-shows at health care appointments" (Latinos \& the New Trump Administration, 2017: pp. 10-11). Gubernskaya and Dreby (2017) write that immigrants:

“... also experience strains in family relationships, especially between fathers and children as men are much more likely to be deported than are mothers ... Recent scholarship also shows significant short- and long-term mental health impacts on children when parents are detained or deported. Children have been shown [to] exhibit significant behavioral effects, including changes in diet and sleep, frequent crying, anxiety, and fear during a deportation event. While some of these symptoms may decrease over time, studies show that withdrawal and angry or aggressive behavior persists.... US citizen children also have been shown to experience higher levels of distress after a parent's deportation regardless of whether they remain in the United States or return to Mexico with their parents ... It is not only a deportation or detention that negatively impacts families: the threat of ... the fear of 'deportability' alone has significant repercussions. Young children in Latino families in the United States have reported fears of separation even when their parents have never had any trouble with the law, fears that were even repeated by children whose parents were legal migrants to the United States" (pp. 422-425; also see Partelow \& Wolgin, 2018).

Wood (2018) presents a number of negative implications as a result of the Trump administration's immigration policies that separate children from their parents and punish children such as placing them in cages: trauma, threatened attachment, toxic stress and dehumanization (pp. 2-4). According to Cervantes and Walker (2017), "Research shows that harsh immigration enforcement policies have consistently undermined the health, economic security, and overall wellbeing of children in immigrant families" (p. 2). Cervantes and Walker (2017) presented five reasons why the Trump administration's immigration orders harm children: “1) Tear families apart, 2) Harm children's short- and long-term mental health, 3) Undermine children's economic security, 4) Threaten children's access to education and basic needs, and 5) Endanger the lives of asylum-seeking children and families" (p. 2; Linton et al., 2019).

Gubernskaya and Dreby (2017) claim that policy makers must not underesti- 
mate the significant social costs of immigration enforcement. "The deportation of a family member leads to significant family trauma for unauthorized and US citizens alike. Families experience significant short-term and long term economic and emotional hardship following a parents' detention or deportation" (pp. 422-425). Gubernskaya and Dreby (2017) point out that: "In the US context where there is nearly no federal support for immigrants' integration and limited welfare policies, family unity is critical for promoting immigrant integration, social and economic well-being, and intergenerational mobility" (p. 417).

Finally, the separation of immigrant families also brings back memories of the past in the United States when people of color, especially Blacks were separated and family members sold off and moved to different parts of the country (Whiting, 2016; Sassi, 2018; Thornton et al., 2009). According to Thornton et al. (2009):

"Historians, sociologists, and economists have long emphasized the detrimental effects of slave owners' power to sell their slaves and in the process, separate husband from wife, parent from child, and relatives and friends from one another. This power to break up slave families was certainly a destructive and disruptive force in the antebellum slave society. In the interregional slave trade, hundreds of thousands of slaves were moved long distances from their original home and birthplace as the slave economy migrated from the eastern seaboard to Louisiana, Texas, and Arkansas" (p. 71; also see Kaba, 2011b).

\section{Conclusion}

This paper has presented an examination of the Donald Trump administration's immigration policies in his first two and a half years in office, comparing it to the last few years of the Barack Obama administration's immigration policies. The paper first presents background information on the gradual increase in educational attainment and wealth accumulation across the world in the past several decades. This increase in educational attainment and wealth accumulation is noted to be due to international migration, which has increased from 173 million in the year 2000 to almost 258 million in 2017. The number of billionaires in the world increased from 140 in 1987 to 2153 in March 2019. The United States is noted to have made significant contributions to the increase in international migration, educational attainment, and wealth accumulation across the world in the past several decades. International migration is a result of religious freedom, political freedom, and economic freedom or opportunity. The United States leads the world in hosting international migrants in 2017, with almost 50 million migrants.

The paper points out a serious concern, which is that compared to the Barack Obama administration, the Donald Trump administration is significantly reducing immigration to the United States and discouraging people from emigrating to the United States and making skilled and unskilled immigrants in the 
United States to consider leaving the country. The Trump administration's immigration measures are causing a lot of anxiety for immigrants in the United States and people across the world. This development could result in the United States losing highly talented or skilled immigrants, which could negatively impact the American economy and society. It is useful to note that it might still be too early to get a better understanding of the Trump administration's immigration policies since this paper only covers his first two and a half years in office, compared with Barack Obama's tenure of eight years in office. However, the data revealed that there are major differences between the two administrations' immigration policies.

\section{Conflicts of Interest}

The author declares no conflicts of interest regarding the publication of this paper.

\section{References}

Admissions and Arrivals (2019). Admissions and Arrivals. Refugee Processing Center. http://ireports.wrapsnet.org/Interactive-Reporting/EnumType/Report?ItemPath=/rpt WebArrivalsReports/Map\%20-\%20Arrivals\%20by\%20State\%20and\%20Nationality

Batalova, J., \& Fix, M. (2017). New Brain Gain: Rising Human Capital among Recent Immigrants to the United States. Migration Policy Institute.

https://www.migrationpolicy.org/research/new-brain-gain-rising-human-capital-amon g-recent-immigrants-united-states

Billionaires (2019). Billionaires: The Richest People in the World. Forbes Magazine. https://www.forbes.com/billionaires/\#7764f8e251c7

Bose, P. S. (2018). Welcome and Hope, Fear, and Loathing: The Politics of Refugee Resettlement in Vermont. Peace and Conflict: Journal of Peace Psychology, 24, 320-329. https://doi.org/10.1037/pac0000302

Cepla, Z. (2019). Fact Sheet: U.S. Refugee Resettlement. National Immigration Forum. https://immigrationforum.org/article/fact-sheet-u-s-refugee-resettlement/

Cervantes, W., \& Walker, C. (2017). Five Reasons Trump's Immigration Orders Harm Children. CLASP.

https://www.clasp.org/publications/report/brief/five-reasons-trump-s-immigration-ord ers-harm-children

CIA (2019). CIA World Factbook. https://www.cia.gov/library/publications/the-world-factbook/geos/us.html

Clarke, K. (2019). Trump Administration at Odds with Catholic Leaders on Immigration Policies. The Jesuit Review.

https://www.americamagazine.org/politics-society/2019/09/20/trump-administration-o dds-catholic-leaders-immigration-policies

Davis, J. H., \& Shear, M. D. (2019). Trump Administration Considers a Drastic Cut in Refugees Allowed to Enter U.S. New York Times.

https://www.nytimes.com/2019/09/06/us/politics/trump-refugees-united-states.html

El-Bawab, N. (2019. Trump's Tough Student and Work Visa Policies Are Pushing Legal Immigrants to Canada. CNBC.

https://www.cnbc.com/2019/02/25/trumps-student-and-work-visa-policies-push-legal- 
immigrants-to-canada.html

Enriquez, L. E., Vazquez Vera, D., \& Ramakrishnan, S. K. (2019). Driver's Licenses for All? Racialized Illegality and the Implementation of Progressive Immigration Policy in California. Law \& Policy, 41, 34-58. https://doi.org/10.1111/lapo.12121

Enrollment Trends (2019). International Student Data. Institute of International Education.

https://www.iie.org/Research-and-Insights/Open-Doors/Data/International-Students/E nrollment

Felter, C., \& Renwick, D. (2019). The U.S. Immigration Debate. Council on Foreign Relations. https://www.cfr.org/backgrounder/us-immigration-debate-0

Global Wealth Report (2018). Global Wealth Report 2018. Credit Suisse Group. https://www.credit-suisse.com/about-us/en/reports-research/global-wealth-report.html

Greene, J. (2019). Confronting Immigration Enforcement under Trump: A Reign of Terror for Immigrant Communities. Social Justice, 45, 83-99.

Grover, T., Bayraktaroglu, E., Mark, G., \& Rho, E. H. R. (2019). Moral and Affective Differences in U.S. Immigration Policy Debate on Twitter. Computer Supported Cooperative Work, 28, 317-355. https://doi.org/10.1007/s10606-019-09357-w

Gubernskaya, Z., \& Dreby, J. (2017). US Immigration Policy and the Case for Family Unity. Journal of Human Security, 5, 417-430.

https://doi.org/10.1177/233150241700500210

Heyer, K. E. (2018). Internalized Borders: Immigration Ethics in the Age of Trump. Theological Studies, 79, 146-164. https://doi.org/10.1177/0040563917744396

Hiemstra, N. (2017). Displacement, Not Deterrence. Journal of Latin American Geography, 16, 171-173. https://doi.org/10.1353/lag.2017.0028

Hill, M. E., \& Wiehe, M. (2017). State \& Local Tax Contributions of Young Undocumented Immigrants. Institute on Taxation \& Economic Policy.

https://itep.org/state-local-tax-contributions-of-young-undocumented-immigrants/

Ibe, P. (2019). Trump's Attacks on the Legal Immigration System Explained. American Friends Service Committee.

https://www.afsc.org/blogs/news-and-commentary/trumps-attacks-legal-immigrationsystem-explained

International Migration Report (2017). International Migration Report 2017 Highlights. United Nations.

http://www.un.org/en/development/desa/population/migration/publications/migration report/docs/MigrationReport2017 Highlights.pdf

Issuance of Certain RFEs \& NOIDs (2018). Revisions to Adjudicator's Field Manual (AFM) Chapter 10.5 (a), Chapter 10.5 (b). Policy Memorandum. PM-602-0163. U.S. Department of Homeland Security.

https://www.uscis.gov/sites/default/files/USCIS/Laws/Memoranda/AFM 10 Standards for RFEs and NOIDs FINAL2.pdf

Kaba, A. J. (2004). Africa's Migration Brain Drain: the Costs and Benefits to the Continent. Chimera, 2, 19-30.

Kaba, A. J. (2009). Africa's Migration Brain Drain: Factors Contributing to the Mass Emigration of Africa's Elite to the West. In I. Okpewho, \& N. Nzegwu (Eds.), Chapter 5, The New African Diaspora (pp. 109-123). Bloomington, IN: Indiana University Press.

Kaba, A. J. (2011a). The Status of Africa's Emigration Brain Drain in the 21st Century. Western Journal of Black Studies, 35, 187-207. 
Kaba, A. J. (2011b). Race, Conquest and Revenge: Why Do Black People Resist Racial Revenge? International Journal of Humanities and Social Science, 1, 92-106.

Kaba, A. J. (2012). Analyzing the Anglo-American Hegemony in the Times Higher Education Rankings. Education Policy Analysis Archives, 20, 1-53. https://doi.org/10.14507/epaa.v20n21.2012

Kaba, A. J. (2017). America's 'Great Immigrants': An Analysis of Carnegie Corporation's Honorees, 2006-2015. London: Adonis \& Abbey Publishers Ltd.

Khullar, D., Blumenthal, D. M., Olenski, A. R., \& Jena, A. B. (2017). U.S. Immigration Policy and American Medical Research: The Scientific Contributions of Foreign Medical Graduates. Annals of Internal Medicine, 167, 584-586. https://doi.org/10.7326/M17-1304

Kilachand, S. (2012). Forbes History: The Original 1987 List of International Billionaires. Forbes Magazine.

https://www.forbes.com/sites/seankilachand/2012/03/21/forbes-history-the-original-19 $\underline{\text { 87-list-of-international-billionaires/\#8106c2a447e8 }}$

Kishi, K. (2018). Key Findings on the Global Rise in Religious Restrictions. Pew Research Center.

http://www.pewresearch.org/fact-tank/2018/06/21/key-findings-on-the-global-rise-in-r eligious-restrictions/

Klingner, D. (2018). Trump against the World: His Policies Toward Mexico, and the Resistance from Inside and Outside the United States. Public Integrity, 20, 1-8. https://doi.org/10.1080/10999922.2017.1368621

Kocher, A. (2017). The New Resistance: Immigrant Rights Mobilization in an Era of Trump. Journal of Latin American Geography, 16, 165-171. https://doi.org/10.1353/lag.2017.0027

Landgrave, M., \& Nowrasteh, A. (2019). Criminal Immigrants in 2017 Their Numbers, Demographics, and Countries of Origin. Immigration Research and Policy Brief, 11, $1-8$.

https://www.cato.org/publications/immigration-research-policy-brief/criminal-immigr ants-2017-their-numbers-demographics

Lind, D., \& Zarracina, J. (2019). By the Numbers: How 2 Years of Trump's Policies have Affected Immigrants. VOX.

https://www.vox.com/policy-and-politics/2019/1/19/18123891/state-of-the-union-2019 -immigration-facts

Linton, J. M., Nagda, J., \& Falusi, O. O. (2019). Advocating for Immigration Policies that Promote Children's Health. The Pediatric Clinics of North America, 66, 619-640. https://doi.org/10.1016/j.pcl.2019.02.009

M'Cormack-Hale, F. A. O., \& Kaba, A. J. (2015). The Obama Administration and U.S.-Africa Relations. Western Journal of Black Studies, 39, 238-255.

Maurer, R. (2018). USCIS Proposes Changes to H-1B Visa Lottery. Society for Human Resource Management. https://www.shrm.org/resourcesandtools/hr-topics/talent-acquisition/pages/uscis-prop oses-changes-to-h-1b-visa-lottery-.aspx

Mayda, A. M., \& Peri, G. (2017). The Economic Impact of US Immigration Policies in the Age of Trump. In C. P. Brown (Ed.), Economic and Policy in the Age of Trump. London: CEPR Press. https://voxeu.org/pages/contact-us

Mazrui, A. A., \& Kaba, A. J. (2016). The African Intelligentsia: Domestic Decline and Global Ascent. Trenton, NJ: Africa World Press.

Mazza, J. (2017). The US-Mexico Border and Mexican Migration to the United States: A 
21st Century Review. The SAIS Review of International Affairs, 37, 33-47. https://doi.org/10.1353/sais.2017.0025

McHugh, M. (2018). In the Age of Trump: Populist Backlash and Progressive Resistance Create Divergent State Immigrant Integration Contexts. Migration Policy Institute. https://www.migrationpolicy.org/research/age-trump-populist-backlash-and-progressi ve-resistance-create-divergent-state-immigrant

Molla, R. (2019). Canada Is Becoming a Tech Hub. Thanks, Donald Trump! Vox. https://www.vox.com/2019/3/19/18264391/us-tech-jobs-canada-immigration-policies-t rump

Montoya, S. (2018). From Brain Drain to Gain: The Benefits Arising from International Knowledge Networks. Network for International Policies and Cooperation in Education and Training (NORRAG).

https://www.norrag.org/from-brain-drain-to-gain-the-benefits-arising-from-internatio nal-knowledge-networks-by-silvia-montoya/

National Security \& Defense (2019). Presidential Proclamation on Declaring a National Emergency Concerning the Southern Border of the United States. The White House. https://www.whitehouse.gov/presidential-actions/presidential-proclamation-declaringnational-emergency-concerning-southern-border-united-states/

Naudé, W. (2012). Migration, Remittances and Resilience in Africa. United Nations University.

https://unu.edu/publications/articles/migration-remittances-and-resilience-in-africa.ht $\underline{\text { ml\#info }}$

Partelow, L., \& Wolgin, P. E. (2018). The Trump Administration's Harsh Immigration Policies Are Harming Schoolchildren. Center for American Progress. https://www.americanprogress.org/issues/education-k-12/news/2018/11/30/461555/tru mp-administrations-harsh-immigration-policies-harming-schoolchildren/

Patel, F., \& Levinson-Waldman (2017). The Islamophobic Administration. Brennan Center for Justice.

https://www.brennancenter.org/publication/islamophobic-administration

Pew Research Center Staff (2017). Latinos and the New Trump Administration. Pew Research Center.

http://www.pewhispanic.org/2017/02/23/latinos-and-the-new-trump-administration/

Pierce, S., \& Capps, R. (2017). Trump Executive Order and DHS Guidance on Interior Enforcement: A Brief Review. Migration Policy Institute.

https://www.migrationpolicy.org/research/trump-executive-order-and-dhs-guidance-i nterior-enforcement-brief-review

Pierce, S., Bolter, J., \& Selee, A. (2018a). Trump's First Year on Immigration Policy: Rhetoric vs. Reality. Migration Policy Institute.

https://www.migrationpolicy.org/research/trump-first-year-immigration-policy-rhetor ic-vs-reality

Pierce, S., Bolter, J., \& Selee, A. (2018b). U.S. Immigration Policy under Trump: Deep Changes and Lasting Impacts. Migration Policy Institute.

https://www.migrationpolicy.org/research/us-immigration-policy-trump-deep-changes -impacts

Reich, G. (2018). Hitting a Wall? The Trump Administration Meets Immigration Federalism. Publius: The Journal of Federalism, 48, 372-395.

https://doi.org/10.1093/publius/pjy013

Robbins, L. M. (2018). The Truth behind U.S. Immigration Policy: Human Development as an Alternative to Border Security. Towson University Journal of International Af- 
fairs, 52, 44-60.

Rose-Redwood, C. A., \& Rose-Redwood, R. (2017). Rethinking the Politics of the International Student Experience in the Age of Trump. Journal of International Students, 7, I-IX. https://doi.org/10.32674/jis.v7i3.201

Roth, B. J., Crea, T. M., Jani, J., Underwood, D., Hasson, R. G., Evans, K., Zuch, M., \& Hornung, E. (2018). Detached and Afraid: U.S. Immigration Policy and the Practice of Forcibly Separating Parents and Young Children at the Border. Child Welfare, 96, 29-49.

Sassi, J. D. (2018). The Legacies of James McCarty: The Story of How Quakers Secured One Family's Emancipation and Its Ramifications for Revolutionary Era Antislavery. Early American Studies: An Interdisciplinary Journal, 16, 282-316.

https://doi.org/10.1353/eam.2018.0010

Shacknove, A. E. (1985) Who Is a Refugee. Ethics, 95, 274-284. https://doi.org/10.1086/292626

Singh, S. B. (2018). An Anthropological Analysis of the Migration Crisis in Sweden: Perceptions of Swedes on Refugees. The Oriental Anthropologist, 18, 177-195. https://doi.org/10.1177/0976343020180201

Stone, R. I., \& Bryant, N. (2018/2019). The Politics of Immigration: Who Will Care for Grandma? Generations, 42, 50-56.

Table 1 (2019). Immigrant and Nonimmigrant Visas Issued at U.S. Foreign Service Posts Fiscal Years 2014-2018. U.S. State Department.

https://travel.state.gov/content/travel/en/legal/visa-law0/visa-statistics/nonimmigrantvisa-statistics.html

Table 19 (2019). Doctorate Recipients, by Ethnicity, Race, and Citizenship Status: 2008-17. National Center for Science and Engineering Statistics. National Science Foundation. https://ncses.nsf.gov/pubs/nsf19301/data

TABLE 35 (2019). Doctorate Recipients' Primary Source of Financial Support, by Broad Field of Study, Sex, Citizenship Status, Ethnicity, and Race: 2017. National Center for Science and Engineering Statistics. National Science Foundation. https://ncses.nsf.gov/pubs/nsf19301/data

Table 53 (2019). Doctorate Recipients with Temporary Visas Intending to Stay in the United States after Doctorate Receipt, by Country of Citizenship: 2011-17. National Center for Science and Engineering Statistics. National Science Foundation. https://ncses.nsf.gov/pubs/nsf19301/data

Table A1.2. (2017). Trends in Educational Attainment of 25-34 Year-Olds (2000, 2005, 2010, 2015 and 2016). Education at a Glance. OECD INDICATORS. OECD. http://download.inep.gov.br/acoes internacionais/eag/documentos/2017/relatorio edu cation at a glance 2017.pdf

Table II (2019). Fiscal Years 2014-2018 Classes of Immigrants Issued Visas at Foreign Service Posts. U.S. State Department.

https://travel.state.gov/content/dam/visas/Statistics/AnnualReports/FY2018AnnualRep ort/FY18AnnualReport\%20-\%20TableII.pdf

Table VII (2019). Immigrant Number Use for Visa Issuances and Adjustments of Status in the Diversity Immigrant Category Fiscal Years 2015-2018. U.S. Department of State. https://travel.state.gov/content/dam/visas/Statistics/AnnualReports/FY2018AnnualRep ort/FY18AnnualReport\%20-\%20TableVII.pdf

The Trump Immigration Agenda (2018). The Trump Immigration Agenda: Timeline of Events: January 2017-August 2018. American Bar Association. https://www.americanbar.org/content/dam/aba/administrative/immigration/trump im 
migration agenda timeline.pdf

Thornton, M., Yanochik, M. A., \& Ewing, B. T. (2009). Selling Slave Families down the River: Property Rights and the Public Auction. The Independent Review, 14, 71-79.

Thumpson, J. (2016). Donald Trump's Foreign Policy: McCarthyism as a Cautionary Tale. CSS Policy Perspectives, 4, 1-4.

Treyz, F., \& Evangelakis, P. (2018). Immigration and United States Economic Growth. Business Economics, 53, 134-140. https://doi.org/10.1057/s11369-018-0084-2

U.S. Department of Homeland Security (2019). Yearbook of Immigration Statistics. https://www.dhs.gov/immigration-statistics/yearbook

Whiting, G. M. (2016). Power, Patriarchy, and Provision: African Families Negotiate Gender and Slavery in New England. The Journal of American History, 103, 583-605.

Wike, R., Stokes, B., Poushter, J., Silver, L., Fetterolf, J., \& Devlin, K. (2018). Trump’s International Ratings Remain Low, Especially among Key Allies Most Still Want US. https://www.pewresearch.org/global/wp-content/uploads/sites/2/2018/10/Pew-Researc h-Center U-S-Image-Report UPDATED 2018-10-01.pdf

Wilson, G. K. (2017). Brexit, Trump and the Special Relationship. The British Journal of Politics and International Relations, 19, 543-557.

https://doi.org/10.1177/1369148117713719

Wood, L. C. (2018). Impact of Punitive Immigration Policies, Parent-Child Separation and Child Detention on the Mental Health and Development of Children. BMJ Paediatrics Open, 2, 1-6. https://doi.org/10.1136/bmjpo-2018-000338

World Bank (2019). World Bank National Accounts Data, and OECD National Accounts Data Files. World Bank Group.

https://data.worldbank.org/indicator/NY.GDP.MKTP.CD? end=2018\&page $=\&$ start $=19$ 60\&view $=$ chart

Young, J. G. (2017). Making America 1920 Again? Nativism and US Immigration, Past and Present. Journal of Migration and Human Security, 5, 217-235.

https://doi.org/10.1177/233150241700500111 